\title{
Barns perspektiv och delaktighet som ideologisk orientering för småbarnspedagogiken i Finland
}

\author{
Jan-Erik Mansikka ${ }^{\star}$, Marina Lundkvist \\ Helsingfors universitet, Pedagogiksa fakulteten, Finland
}

\begin{abstract}
Sammandrag
Barnomsorgen i Finland har en gemensam historia med övriga Norden, dels genom Fröbeltraditionen, dels genom de värderingar som ligger till grund för det nordiska välfärdssamhället. Under en lång tid har daghem och skola utvecklats utifrån olika utgångspunkter och styrprocesser. Men under de senaste åren har dessa kommit att konsolideras i en politiskt underbyggd reform. En tradition av omsorg och fostran för barn mellan 0-6 år omskrivs till småbarnspedagogik, och i den nya läroplanen som tagits i bruk 2017 betonas barns perspektiv och barns delaktighet som centrala utgångspunkter för verksamheten, som en ny ideologisk värdegrund för den moderna småbarnspedagogiken i Finland. I artikeln analyseras vilka uttryck för barns perspektiv och delaktighet som framträder i de finländska styrdokumenten. Vi lyfter också fram olika faktorer som bidragit till att orienteringen mot barns perspektiv och delaktighet etablerats senare i Finland jämfört med de övriga nordiska länderna.
\end{abstract}

Nyckelord: Barns perspektiv; delaktighet; småbarnspedagogik $i$ Finland; läroplan; styrdokument

\section{Abstract \\ Children's Perspectives and Participation as the Ideological Orientation of Early Childhood Education in Finland}

In the Nordic countries, early childhood education and care (ECEC) share the same philosophical tradition and underlying social values. Early childhood institutions have traditionally been developed within a framework quite separate from school development. In Finland, due to recent educational reforms, the two educational institutions seem to be consolidated. The concept of education is today very prominent in the early childhood context. The new curriculum, which has been in use since 2017, emphasizes children's perspective and children's participation as a central point of departure, as significant concepts of a new ideological framework for the modern ECEC. In this article, we analyse what role kinds children's perspective and children's participation have in recent steering documents. We also focus on some factors that contribute to the relatively slow development in incorporating children's perspective and children's participation in the culture of ECEC in Finland, compared to other Nordic countries.

Keywords: Child's perspective; participation; ECEC in Finland; curriculum; steering document

^Korrespondanse: Jan Erik Mansikka, epost: jan-erik.mansikka@helsinki.fi

(C) 2019 Jan Erik Mansikka og Marina Lundkvist. This is an Open Access article distributed under the terms of the Creative Commons Attribution 4.0 International License (https://creativecommons.org/licenses/by-nc/4.0/), allowing third parties to copy and redistribute the material in any medium or format and to remix, transform, and build upon the material for any purpose, even commercially, provided the original work is properly cited and states its license.

Citation: Fan Erik Mansikka og Marina Lundkvist. "Barns perspektiv och delaktighet som ideologisk orientering för småbarnspedagogiken i Finland» Nordisk tidsskrift for pedagogikk og kritikk, Special Issue: "Barneperspektiv» 
Mottagit: September, 2018; Godkjänt: Mai, 2019; Publicerat: Juni, 2019

\section{Introduktion}

Finland har under 2000-talet fått en ny identitetsmarkör i och med att det börjat betraktas som ett "utbildningsland" (Sahlberg, 2015). Bakgrunden ligger i att PISAundersökningarna som, alltsedan de första resultaten publicerades 2001, har gett den finländska skolan stor internationell synlighet, otaliga besök av delegationer inom utbildningsfrågor samt en framväxande utbildningsexport (se Reinikka, Niemi \& Tulivuori, 2018). Småbarnspedagogiken har inte fått ta del av internationellt strålkastarljus i samma grad som skolan, men under de senaste åren har betydelsefulla strukturella förändringar genomförts som knyter dessa båda pedagogiska institutioner närmare varandra.

Viktiga förändringar är att den administrativa hemvisten för dagvårdsverksamheten år 2013 flyttade från den sociala sektorn till undervisningssektorn. Några år senare skapades en ny lag om småbarnspedagogik (540/2018), vars första fas trädde i kraft 2015 (580/2015), och vilket innebar en betydande förskjutning från ett omsorgstänkande till en mera pedagogisk referensram. Den nya lagen förde också med sig nya bestämmelser gällande fördelning av personalstrukturen på daghemmen, där personalens pedagogiska kompetens i allt högre grad betonas. Dessutom har småbarnspedagogiken sedan 2017 reglerats av en helt ny läroplan, Grunderna för planen för småbarnspedagogik (här: GP16). ${ }^{1}$

Utbildningsfrågor bygger alltid på sociala och kulturella traditioner. Det gäller även för barnomsorg, som i Finland har en lång gemensam historia med övriga Norden, dels genom Fröbeltraditionen (Meretniemi, 2015), dels i hög grad genom värderingar som ligger till grund för den nordiska välfärdspolitiken (Alila m.fl., 2014). ${ }^{2}$ Barndomens institutionalisering, kännetecknande för det nordiska välfärdssamhället, kan ses som ett uttryck för en tilltagande sekularisering, för en modernitet som präglas av ökad jämlikhet mellan könen och religionens förminskade roll i uppfostran (Kjørholt \& Qvortrup, 2012, s. 1). Statistiken visar att det är närmast en norm att barn under skolålder i Norden deltar i småbarnspedagogisk verksamhet ${ }^{3}$, vilket ställer krav på att

${ }^{1}$ I Finland benämns det nya styrdokumentet inte som en läroplan men har motsvarande funktion. Den "har som uppdrag att stödja och styra hur småbarnspedagogiken ordnas, genomförs och utvecklas" (GP16, s. 8).

${ }^{2}$ Utvecklingen av den finländska dagvården kan sägas följa en gemensam nordisk välfärdsmodell, som började ta form efter andra världskriget. Denna modell gav upphov till nya samhälleliga institutioner, med både tjänster och stöd för moderskapet samt politiska satsningar på förebyggande barn- och ungdomsverksamhet (Satka \& Eydal, 2004, s. 40). De nordiska länderna har beskrivits som föregångsland i fråga om barnperspektiv och barns perspektiv genom olika politiska beslut: en barnombudsman, en lag mot barnaga samt en läroplan som betonar barns delaktighet uppmuntrar till en förhandlingskultur mellan vuxna och barn (Pramling Samuelsson m.fl., 2011, s. 17).

${ }^{3}$ Traditionen av hemvård har varit stark i Finland men det har skett en märkbar ökning av institutionell dagvård under hela 2000-talet. År 2017 deltog ca 82 \% av barnen i åldern 3-5 år inom kommunalt eller privat ordnad småbarnspedagogik i Finland medan motsvarande andel i Sverige, Norge och Island var kring 95 \%, se https://www.nordicstatistics.org/education. 
förstå den moderna institutionella barndomen (Pramling Samuelsson, Sommer \& Hundeide, 2011, s. 24).

Den institutionaliserade dagvården i Finland följer i det stora hela samma utvecklingsförlopp som i de övriga nordiska länderna (se Kampmann, 2004; Alasuutari, 2009; Strandell, 2012). Man kan tala om en första våg av barndomens institutionalisering som uppkom på 1960-talet till följd av att man började betrakta dagvården som en verksamhet för hela samhället. Den var en naturlig följd av att kvinnorna i större skara tog sig ut i arbetslivet. Dagvårdens uppgift sågs ändå i första hand som ett "tillägg" till hemmet, där ansvaret för fostran betonades ligga hos familjen (Kampmann, 2004, s. 133). En andra våg av institutionalisering ägde rum då man på 1990-talet började betrakta dagvården allt mera utifrån en ny pedagogisk kontext, med grund i en framväxande expertis förankrad i vetenskaplig forskning. Fokus kom att riktas på kvalitativa målsättningar och konkret utveckling av själva dagvårdsverksamheten. Men den blev också underkastad samma ekonomiska effektivitet och rationella planering som hela den övriga offentliga sektorn (Kampmann, 2004; Strandell, 2012).

I denna artikel belyser vi utvecklingen av småbarnspedagogiken i Finland i terrängen för den andra vågen av barndomens institutionalisering. Denna våg förde med sig nya småbarnspedagogiska betoningar, där barnets individualitet och unika personlighet starkare än tidigare kom att träda i förgrunden, framom allmänna utvecklingspsykologiska teorier (Alasuutari, 2009). Utvecklingen sammanfaller med att man allt oftare också började hänvisa till $\mathrm{FN}$ :s konvention om barnets rättigheter från 1989, som Finland ratificerade 1991. Av barnkonventionens olika teman är det barns delaktighet som allra mest blivit föremål för småbarnspedagogisk forskning under 2000-talet i Finland (Turja \& Vuorisalo, 2018).

I artikeln analyseras vilka uttryck för barns perspektiv och delaktighet som framträder i de senaste finländska styrdokumenten. Vi har valt dessa båda begrepp för att det finns ett stort behov i Finland att förhålla sig till dessa begrepp i samband med den nya planen (Turja, 2017; Helin, Kola-Torvinen \& Tarkka, 2018). Vi ser begreppen i ett ideologiskt ljus, både i bemärkelsen att de beskrivs som framtidsorienterade byggstenar i den småbarnspedagogiska värdegrunden, och i att de styr småbarnspedagogiken i riktning mot ett demokratiskt samhällsideal. Vår övergripande målsättning är att försöka belysa hur orienteringen mot barns perspektiv och delaktighet i Finland är sammanlänkad med att småbarnspedagogiken kommit att formuleras i en tydligare pedagogisk referensram.

Artikeln har följande form. Vi behandlar först begreppen barnperspektiv, barns perspektiv och delaktighet med betoning på den finländska kontexten. Därefter analyseras hur barns perspektiv och delaktighet framträder i förhållande till de senaste reformerna inom småbarnspedagogik i Finland, och alldeles särskilt i förhållande till de två senaste finländska styrdokumenten inom småbarnspedagogik. I den avslutande sammanfattningen knyter vi ihop vårt resonemang för att peka på den förändring som har ägt rum under 2000-talet. 


\section{Nedslag i begreppen barns perspektiv och delaktighet}

De professionella kraven på lärare som jobbar med barn under skolåldern har ökat märkbart under de senaste årtiondena, både $\mathrm{i}$ ett nordiskt och globalt perspektiv (Garvis m.fl., 2018). En av de största förändringarna gäller kravet på att se barnet ur ett aktörsperspektiv. Det har sagts att det starka fokus som finns på barnet som en unik individ är "en av de mest anmärkningsvärda och bestående trenderna på senare tid" $i$ de nordiska länderna med föräldrar som förväntar sig att barnen ska utveckla en självständighet i ett tidigt skede samt ges möjlighet att bli både "sedda" och "hörda" (Pramling Samuelsson m.fl., 2011, s. 30-31). Barns perspektiv och delaktighet är viktiga begrepp i denna individualiseringsretorik.

\section{Diskussionen om barnperspektiv eller barns perspektiv}

Intresset för ett barnperspektiv växer fram ur ett behov att fånga ett särskilt perspektiv som, på grund av maktförhållandet mellan vuxna och barn, tidigare inte synliggiorts. Att inta ett barnperspektiv är ändå inte något självklart och rätlinjigt. På grund av det asymmetriska förhållande som råder mellan vuxna och barn uppkommer frågan vems perspektiv som det är önskvärt att det sist och slutligen kommer i förgrunden. Detta har gett upphov till en rätt livlig diskussion, där man särskilt i Norden aktivt diskuterat skillnaden mellan barnperspektiv och barns perspektiv (t.ex. Kinos, 2002; Halldén, 2003; Johansson, 2003; Arnér \& Tellgren, 2006; Niikko, 2009; Pramling Samuelsson m.fl., 2011).

Halldén (2003, s. 3) skriver att

[b]arnperspektiv skrivet som ett ord sätter fokus på ett perspektiv som syftar till att tillvarata barns villkor och verka för barns bästa eller för att studera en kultur skapad för barn. Sett som två ord [barns perspektiv] blir det i stället att anlägga ett perspektiv eller fånga en kultur som är barnets.

Detta är i linje med hur distinktionen uppfattas t.ex. av Pramling Samuelsson m.fl. (2011): Ett barnperspektiv eftersträvar att öka förståelsen av barn med hjälp av vuxnas tolkningar av barnens sätt att vara i världen - genom att rekonstruera deras uppfattningar, erfarenheter och handlingar till begrepp - och trots att ett barncentrerat perspektiv kommer "alltid att representera vuxnas objektifiering av barn" (Pramling Samuelsson m.fl., s. 42). Barns perspektiv är däremot starkare förankrat i barnet som subjekt i sin egen värld, på barnets egen fenomenologi” (Pramling Samuelsson m.fl., s. 42). Här ligger fokus mera på beskrivningen av barns erfarenheter och uppfattningar, barnens egen livsvärld. Barnperspektiv och barns perspektiv är alltså inte synonyma men ofta förgivettagna som barns "röster". Den ena rösten är mera filtrerad genom den vuxna än den andra.

Skillnaden mellan barnperspektiv och barns perspektiv [fi. lapsikeskeisyys ja lapsilähtöisyys] har diskuterats i Finland fr.o.m. 1990-talet. Inom forskning och lärarutbildning började man tala om barns perspektiv som ett komplement till 
barnperspektiv, som dittills fungerat som motsatspar till en vuxenstyrd pedagogik (se t.ex. Hytönen, 1992; Kinos, 2002; Brotherus m.fl., 2002). Barns perspektiv kom att kritiseras från akademiskt håll på grund av den starka individfokuseringen. I Brotherus m.fl. (2002) beskrivs barns perspektiv i ljuset av romantikens syn på barnet, och som försummar tre viktiga aspekter av den moderna pedagogiken: läroplanens och andra styrdokuments betydelse, fostrarens aktiva inflytande på barnet och pedagogikens samhälleliga dimension (Brotherus m.fl.). Här, liksom i Hytönen (1992), får barns perspektiv en rätt kritisk behandling. Barns perspektiv lyckades därför inte i början av 2000-talet slå rot i något fruktbart teoretiskt sammanhang (Kinos, 2002). Också när det gäller den finländska skolan kom en elevcentrerad undervisning att växa fram först efter millennieskiftet. Forskning visar att lärare i Finland överraskande länge upprätthållit en rätt konservativ roll, där auktoritet och distans till eleverna varit viktiga egenskaper (se Simola, 2015).

En småbarnspedagogik som aktivt arbetar med att synliggöra barns intressen, som Kinos (2002) förespråkade, var ännu i början av 2000-talet rätt avvikande från det allmänna pedagogiska etoset i Finland. Detta förklarar i sin tur att kommittén, som övervakar FN:s barnkonvention, i sin rapport om Finland 2011 riktade tydliga rekommendationer för Finlands del när det gäller att synliggöra barns röst och delaktighet (Council of Europe, 2011, s. 121). Rapporten rekommenderade också att bereda en ny lag inom småbarnspedagogik för att stärka barns rättigheter i samhället. Denna förverkligades 2015, men det har påpekats att förändringarna på många punkter har realiserats långsamt (se Puroila \& Kinnunen, 2017).

På det stora hela kan man säga att tematiken kring "barnperspektiv eller barns perspektiv" inte fått särskilt stor uppmärksamhet i Finland, särskilt innan man började bereda den nya lagen. Det har funnits ett starkt antagande om att det visserligen är lätt att aktivera barn genom en pedagogik som tar sin utgångspunkt $i$ barns intressen, men följden av detta kan vara att läraren passiveras och glömmer sitt ansvar och sin auktoritet som lärare (Hytönen, 1992; Brotherus m.fl., 2002). I ett sådant resonemang framställs barns och vuxnas perspektiv i ett motsatsförhållande: barns intressen och lärarens pedagogiska målsättningar är oförenliga. Denna utgångspunkt har bidragit till att barnperspektiv, till syvende och sist, framträder som en naturligare teoretisk utgångspunkt för småbarnspedagogiken än barns perspektiv (Niikko, 2009), trots att betydelsefulla ansatser för barns perspektiv också utvecklats (se Karlsson, 2012; Kangas, 2016). De allra senaste åren har tematiken fått förnyad aktualitet i Finland, särskilt genom diskussionen kring barns delaktighet.

\section{Barns delaktighet inom småbarnspedagogiken}

Forskning visar att Finland implementerat barns rättigheter och barns delaktighet i samhället långsammare än de övriga nordiska länderna. Försök att utveckla och upprätta nya strukturer för barns delaktighet i saker som berör barnen själva har i Finland ofta överlämnats till små, kortvariga och experimentella projekt (Satka \& Eydal, 2004; Karila, 2009). Under 2000-talet har man ändå, i olika sammanhang, 


\section{fan Erik Mansikka og Marina Lundkvist}

börjat utveckla pedagogiska verksamhetsmodeller där man eftersträvar att lyssna till barnen och intressera sig för deras åsikter och initiativ. Målet har varit att göra barnen mer delaktiga i den dagliga daghemsverksamheten, bl.a. genom valfrihet samt möjlighet att delta i gemensamma aktiviteter och beslutsfattande (Karila, 2006; Hännikäinen \& Rasku-Puttonen, 2010; Karlsson, 2012).

Frågor kring barns delaktighet började få mera synlighet i samhället efter att Finland fick en barnombudsman 2005 (Lag om barnombudsmannen 1221/2004). Under senare år har forskning med explicit fokus på barns delaktighet inom småbarnspedagogiken vuxit fram (bl.a.Venninen \& Leinonen, 2013; Venninen, Leinonen, Lipponen \& Ojala, 2014; Kangas, 2016; Turja, 2017) men också indirekt genom forskning fokuserad på delaktighet som en central dimension av demokrati (Lundkvist, 2016). Det är tydligt att den småbarnspedagogiska diskussionen kring delaktighet i Finland rätt länge har betonat gemenskap och samverkan som grundläggande verksamhetsprinciper och det har funnits ett visst motstånd mot att utveckla verksamhetskulturen utgående från barns perspektiv (se Niikko, 2009; Hännikäinen \& Rasku-Puttonen, 2010). Vi möter här en intressant spänning mellan individ och gemenskap i förhållande till begreppet delaktighet, som vi i detta sammanhang ska försöka artikulera något tydligare.

Isaiah Berlin har initierat en diskussion mellan negativ och positiv frihet inom samhällsfilosofin (se Berlin, 1969), som även kan utnyttjas i en småbarnspedagogisk kontext (se Varpanen, 2018). Berlin beskriver den negativa friheten härstammande från en liberalistisk tradition där samhällets institutioner i första hand ses som begränsningar för individens frihet. Det viktiga i denna form av frihet är att andra personer inte kommer åt att påverka individens val, utan individen är fri att välja själv. Ju mindre människan begränsas av det omgivande samhällets bestämmelser eller regler, eller andra människors viljor, desto friare är människan (Berlin, 1969). Den positiva friheten framspringer däremot ur en tradition, $i$ vilken det omgivande samhällets institutioner ses som identitetsskapande och erbjuder möjligheter som människan inte ensam skulle kunna förverkliga. Här kommer den omgivande världen, inte individens vilja, i fokus. Berlin frågar vem som ansvarar och skapar de sammanhang och värderingar som utgör grunden för individens val (Berlin, 1969). Hannah Arendt hänvisar till denna dimension när hon säger att utan en gemenskap förankrad i ett samhälle saknar friheten "ett rum där den kan framträda", och menar att vår filosofiska tradition har kommit att fördunkla frihetens idé - genom att förflytta den från det mellanmänskliga till människans inre, till viljan (Arendt, 2004, s. 163).

Båda frihetsbegreppen har en motsvarighet i hur vi kan förstå barns delaktighet inom den småbarnspedagogiska verksamheten. Man kan se den negativa friheten åberopas i alla de sammanhang man eftersträvar att stödja barns delaktighet genom att öka deras valfrihet. Det är rätt vanligt i Finland att barnen på daghemmen får välja lek genom s.k. "lekvalstavla". Istället för att välja helt fritt vad man leker, så väljer man utifrån ett begränsat urval alternativ som de vuxna har ställt till förfogande. Ett problem med denna typ av valfrihet för små barn kan vara att trots att vi ger alla barn möjligheter 
att välja, kan vi ändå inte garantera att alla kan välja på lika villkor. Det finns ofta olika typer av osynliga begränsningar, kategoriseringar och maktskillnader som valfriheten osynliggör (se Dolk, 2013). Ökad empirisk forskning i Finland pekar på att barns delaktighet i de allra flesta fall ännu i dag tolkas rätt snävt inom den småbarnspedagogiska verksamheten, t.ex. i betydelsen att låta barnen uttrycka sina preferenser i tur och ordning (Leinonen, 2014; Lundkvist, 2015, 2016; Turja, 2017; Brotherus \& Kangas, 2018). Då tolkas delaktighet endast i den negativa frihetens dimension.

Det positiva frihetsbegreppet visar sig i sammanhang där delaktighet inte endast blir en fråga om vilja och valfrihet, utan snarare handlar om att erbjuda en verksamhetsmiljö, möjligheter till ett rum, där varje barn blir synligt och utvecklas på sitt individuella sätt. Delaktighet förutsätter därför för barnens del "meningserbjudanden och skapande av möjlighetsrum" (Qvarsell, 2011, s. 68). Trots att barnet i dag betraktas som en kompetent och en individuell aktör, så utgår småbarnspedagogiken samtidigt från en långsiktig och planerad lärandeprocess, där ansvaret vilar på de vuxna (Leinonen, 2014; Lundkvist, 2016). Rent konkret kan barns delaktighet, sedd ur den positiva frihetens perspektiv, innebära olika saker, allt från en trygg miljö till att vuxna reflekterar över verksamheten och de sociala relationerna tillsammans med barnen, utifrån samma "delade verklighet" (Varpanen, 2018).

Under senare år har man i Finland kommit att utveckla teorier kring delaktighet i ett pedagogiskt perspektiv som beaktar både individuella och gemenskapsrelaterade element. En välutvecklad teoretisk referensram finner man i Kangas (2016), där barnets individuella inflytande är i ett samspel med pedagogernas tänkande och den politiska och sociala kontexten (jfr Venninen \& Leinonen, 2013; Leinonen, 2014). En viktig poäng i detta sammanhang är att individ och gemenskap inte står i ett motsatsförhållande - liksom inte heller negativ och positiv frihet. De är snarare förutsättningar för varandra.

\section{Kvalitativ analys av två finländska styrdokument inom småbarnspedagogik}

I detta avsnitt gör vi ett empiriskt nedslag i de två senaste styrdokumenten inom småbarnspedagogik i Finland. Vi har tidigare beskrivit hur barns perspektiv och delaktighet under 2000-talet etablerat sig inom den småbarnspedagogiska litteraturen och forskningen i Finland. Genom att fokusera på de två senaste finländska styrdokumenten inom småbarnspedagogik, och det sätt barns perspektiv och delaktighet framträder i dem, vill vi undersöka vilken roll dessa begrepp har i den förändringsprocess som kännetecknar småbarnspedagogiken i Finland de senaste åren.

Vi behandlar två styrdokument som är skapade i ganska olika sammanhang, men båda är riktgivande för småbarnspedagogikens mål, innehåll och centrala verksamhetsområden. ${ }^{4}$ Det tidigare dokumentet, Grunderna för planen för småbarnsfostran,

${ }^{4}$ En betydelsefull skillnad är att GP16 till sitt innehåll är "juridiskt bindande" (s. 9), medan GP05 beskrevs som ett "styrmedel på nationellt plan" (s. 11). 


\section{fan Erik Mansikka og Marina Lundkvist}

trädde i kraft 2003 med en reviderad upplaga 2005 (här: GP05), utgavs av Stakes, underställd social- och hälsovårdssektorn. ${ }^{5}$ Dokumentet ersattes 2016 av det nuvarande styrdokumentet, Grunderna för planen för småbarnspedagogik (här: GP16) utgiven av Utbildningsstyrelsen. ${ }^{6}$ Både finsk- och svenskspråkiga daghem i Finland använder samma styrdokument. I vår analys använder vi oss av den svenska översättningen. Både GP05 och GP16 består ungefär av lika mycket text, den nyare planen något mer (GP05/50 sidor; GP16/63 sidor).

Analysen av styrdokumenten bygger på en kvalitativ tematisk textanalys (Bryman, 2011; Tjora, 2012). I likhet med nordiska studier av Einarsdottir m.fl. (2015) eller Eriksen (2018) närmar vi oss texterna både genom förekomsten av vissa ord och centrala begrepp som relateras till innehållet som helhet. Vi intresserar oss särskilt för likheter och skillnader samt hur vissa begrepp skiftar innebörd över tid. Widén (2009) skiljer mellan tre olika analytiska dimensioner av textanalys. Den första dimensionen handlar om textens innehåll så som författaren har avsett den, medan man i den andra dimensionen riktar fokus mot textens språkliga och litterära kvaliteter. I den tredje dimensionen analyseras texterna mot bakgrund av det omgivande samhället i vilken texterna producerats. Vår analys utgår från att jämföra två styrdokument och synliggöra hur vissa begrepp framträder i dokumenten för att diskutera resultaten $i$ en småbarnspedagogisk kontext. Vi navigerar således i analysen mellan den första och tredje dimensionen av textanalys.

Vi började med att läsa igenom dokumenten med avseende på våra centrala begrepp, barns perspektiv och delaktighet (steg 1). Dessa begrepp förekom i rätt liten utsträckning varför vi utvidgade vår sökning till närbesläktade begrepp till delaktighet såsom begreppen delta, inflytande, initiativ, demokrati samt lärande och fostran. Genom dem kunde vi identifiera olika sammanhang där liknande tematik kunde tänkas indirekt framträda. Totala antalet närbesläktade begrepp som vi utgått ifrån var ca 30 och i analysen redovisas vissa av dem (tabell 1, 2 och 3). Med tabellerna vill vi närmast påvisa hur förekomsten av vissa begrepp skiljer sig till antal i de två olika dokumenten (steg 2).

I vår genomläsning av dokumenten, och utgående från våra centrala och närbesläktade begrepp, identifierade vi tre olika sammanhang som upplevdes meningsfulla att avgränsa: ett aktörs-, ett lärande- och ett samhällsperspektiv (steg 3). Uppbyggnaden av resultatredovisningen följer dessa tre perspektiv och vår argumentation tar fasta på vissa avsnitt och passager i texten som pekar på en förskjutning av betydelser när man jämför styrdokumenten med varandra. Det kan också handla om begrepp som var frånvarande i det ena dokumentet men betydelsebärande i det andra (steg 4).

\footnotetext{
${ }^{5}$ Organisationer lydande under social- och hälsovårdsministeriet som styrde dagvården var Stakes. Forsknings- och utvecklingscentralen för social- och hälsovården (fram till 2009) och Institutet för hälsa och välfärd (2009-2013).

${ }^{6}$ Utbildningsstyrelsen är ett centralt sakkunnigämbetsverk som lyder under Undervisnings- och kulturministeriet och uppdaterar och upprätthåller de styrdokument som gäller småbarnspedagogik, förskola och skola i Finland.
} 


\section{Barnet som aktör - från individuellt deltagande till delaktighet}

Vi har tidigare nämnt att en av de största förändringarna inom småbarnspedagogiken som FN:s barnkonvention kommit att ge upphov till gäller kravet på att se barnet ur ett aktörsperspektiv. I detta avsnitt ser vi på hur de två styrdokumenten beskriver barnets aktörskap. Båda styrdokumenten tar tydligt avstamp i barnkonventionens 12:e artikel, och det är i första hand i det sammanhang barnet som aktör formuleras. Båda styrdokumenten utgår alltså från barnkonventionen samtidigt som begreppen barns rätt och rättigheter förekommer betydligt mera frekvent i GP16 jämfört med GP05. Detsamma gäller också begrepp som anknyter till delaktighet. Det är intressant att notera att man överhuvudtaget inte nämner barns inflytande i något av dokumenten.

Tabell 1. Närbesläktade begrepp i anslutning till barns perspektiv och delaktighet i ett aktörsperspektiv.

\begin{tabular}{|l|c|c|}
\hline Närbesläktade begrepp & $\begin{array}{c}\text { Antalet gånger begreppet nämnts } \\
\text { GP05 }\end{array}$ & $\begin{array}{c}\text { Antalet gånger begreppet nämnts } \\
\text { GP16 }\end{array}$ \\
\hline Rätt, rättighet & 38 & 80 \\
\hline Delta & 17 & 46 \\
Inflytande & 0 & 0 \\
Initiativ & 6 & 11 \\
\hline Ansvar & 9 & 32 \\
\hline
\end{tabular}

I båda dokumenten framträder barns rättigheter på den mest grundläggande nivån genom den universalism som genomsyrar det nordiska välfärdssamhället - som alla barns rätt till småbarnsfostran/-pedagogik. Vilka särskilda rättigheter som betonas och hur de formuleras varierar mellan dokumenten. I värdegrunden för GP05 utgår man från det individuella barnet som har rätt till:

- trygga människoförhållanden

- att växa upp, utvecklas och lära sig i trygga förhållanden

- en trygg och hälsosam miljö i vilken det är möjligt för barnet att leka och fungera på ett mångsidigt sätt

- att bli förstått och uppmärksammat enligt sin ålder och utvecklingsnivå

- få specialstöd i den mån som sådant behövs

- egen kultur, eget modersmål, egen religion eller livsåskådning (s. 17)

Här hänvisas till att barnet ska omges av trygghet, omsorg och fostran för att växa in $i$ en gemenskap, med respekt för den egna individualiteten. Barnet framträder inte som särskilt aktivt, utan rättigheterna uttrycks närmast $i$ betydelsen av att bli sedd samt att socialiseras in i ett sammanhang. I värdegrunden för GP16 är tonen rätt annorlunda. Man talar inte om det individuella barnet, utan om barnen med

rätt att uttrycka sig, sina tankar och åsikter samt bli förstådda utgående från sina egna förutsättningar att kommunicera och uttrycka sig. Alla barn har rätt till god 
undervisning, omsorg och uppmuntrande respons. Barnen har rätt att leka, lära sig genom lek, glädjas över sitt lärande och bilda sig en uppfattning om sig själva, sina identiteter och världen utifrån sina egna perspektiv. Barnen har rätt till social gemenskap och att vara en del av en grupp. Barnen har rätt att få mångsidig information, hantera känslor och konflikter samt pröva på och lära sig nya saker (GP16, s. 19).

Här framställs barnens rättigheter på ett mera dynamiskt sätt än tidigare. Barnens färdigheter och förmågor beaktas i betydligt större utsträckning än tidigare. I den nya planen framträder föreställningen om det kompetenta barnet och barnet som aktör långt mera nyanserat och utskrivet än vad fallet var i beskrivningen från GP05.

Barnet som aktör får också konturer i anslutning till hur man beskriver barns delaktighet. Barns delaktighet förekommer endast en gång i GP05 och då i en betydelse där de vuxna gör det möjligt att skapa en "tillitsfull atmosfär i vilken barnen kan känna tillhörighet och delaktighet" (GP05, s. 21). Man utgår här från delaktighet närmast i betydelsen av en trygg miljö, med en känsla av sammanhang. Ur ett aktörsperspektiv framställs det enskilda barnet som rätt passivt och barns perspektiv kommer överhuvudtaget inte i fokus.

Diskussionen om barns delaktighet i GP16 framträder däremot i flera olika kontexter, och begreppet nämns 19 gånger. I de allra flesta fall behandlas barns delaktighet $\mathrm{i}$ form av rätten att vara med och planera verksamheten och ingå på ett aktivt sätt i ett större sammanhang. Man betonar en inkluderande verksamhetskultur som

ska främja delaktighet, likabehandling och jämställdhet i all verksamhet. Barnens, personalens och vårdnadshavarnas initiativ, åsikter och synpunkter ska värdesättas. Det förutsätter att man medvetet utvecklar arbetssätt och strukturer som främjar delaktighet (GP16, s. 29).

Det förefaller som om det skett ett perspektivskifte kring barnets aktörskap på två sätt. I det nya styrdokumentet finns ett explicit krav på att uppmärksamma barns perspektiv i planeringen av verksamheten: "Personalen har ansvar för att hitta lämpliga sätt att klarlägga barnets perspektiv" (GP16, s. 1). Trots att GP05 utgår från barnkonventionen och barnet som aktör får barnet en betydligt mer passiv roll i och med att barns perspektiv egentligen inte framträder i dokumentet. Detta överensstämmer med den tidigare observationen att barns perspektiv i mycket liten utsträckning hade blivit föremål för forskning i Finland i början av 2000-talet.

Barns rättigheter behandlas i GP05, i första hand, ur det individuella barnets perspektiv, med betoning att beakta barnets individualitet, för att skapa "en grund för varje enskilt barn att fungera och utvecklas enligt individuella förutsättningar" (GP05, s. 18). I GP16 finns en tydligare betoning på barns rätt att aktivt ingå i gemenskaper med andra barn och vuxna, och vara delaktiga i aktiviteter som erbjuds i daghemmets verksamhetsmiljö. Det finns alltså en slags rörelse från att i GP05 identifiera barnet som ett individuellt subjekt till att, i GP16, beskriva barnet som aktivt och delaktigt i förhållande till en gemenskap. 


\section{Från fostrande gemenskap till lärande gemenskap}

En betydelsefull terminologisk förändring har ägt rum från GP05 till GP16. I GP05 myntades begreppet "småbarnsfostran" på svenska för att motsvara finskans varhaiskasvatus (ordagrant ungefär "tidig fostran"). Man ansåg termen småbarnspedagogik "mindre lämplig i sammanhanget för att den i alltför hög grad för tankarna till den pedagogiska aspekten" (GP05, s. 5). Istället ville man betona helheten av vård, fostran och undervisning. Tio år senare hade tyngdpunkten skiftat, och det stipulerades att "[m]ed småbarnspedagogik avses en systematisk och målinriktad helhet som består av fostran, undervisning och vård, i vilken i synnerhet pedagogiken betonas" (Lagen om ändring av lagen om barndagvård 1 \580/2015). På en begreppslig nivå ser vi alltså en tydlig förskjutning mot en mera pedagogisk lärandekultur. I tabell 2 jämförs förekomsten av relaterade begrepp i de två styrdokumenten som pekar på en förskjutning från fostran och omsorg till en småbarnspedagogik.

Tabell 2. Närbesläktade begrepp i anslutning till barns perspektiv och delaktighet i ett lärandeperspektiv.

\begin{tabular}{|l|c|c|}
\hline Närbesläktade begrepp & $\begin{array}{c}\text { Antalet gånger begreppet nämnts } \\
\text { GP05 }\end{array}$ & $\begin{array}{c}\text { Antalet gånger begreppet nämnts } \\
\text { GP16 }\end{array}$ \\
\hline Lära/lärande & 30 & 178 \\
Småbarnspedagogik & 1 & 495 \\
\hline Fostran & 306 & 45 \\
Småbarnsfostran & 257 & 0 \\
Fostringsgemenskap/ & 36 & 1 \\
fostrande gemenskap & & 8 \\
\hline Gemenskap (lärande) & 2 & 36 \\
Gemenskap (social) & 30 & 79 \\
Samarbete & & \\
\hline
\end{tabular}

Begrepp som anknyter till lärande har fått en betydligt större frekvens i den senare planen, men också formuleringar kring samarbete och olika typer av gemenskap. Båda läroplanerna betonar den omgivande miljöns centrala betydelse när det gäller barns lärande. Men retoriskt har man övergått från en fostrande gemenskap till en lärande gemenskap. Hur framträder detta i förhållande till barns perspektiv och delaktighet?

I GP05 kan man ännu skönja ett visst avstånd mellan barn och vuxna. Begreppet samarbete framträder uteslutande som ett samarbete mellan vuxna. Det finns en ganska tydlig rollfördelning där de vuxna har ansvar för inlärningsmiljön så att barnet $\mathrm{i}$ olika situationer ges möjligheter till fostran och lärande.

Fostrarnas uppgift är att planera verksamheten och att erbjuda barn en miljö som avspeglar dels det sätt som är karakteristiskt för ett barn att fungera på, dels ger uttryck för vissa inriktningar som man på förhand gjort upp ramarna för (GP05, s. 21). 


\section{fan Erik Mansikka og Marina Lundkvist}

I GP05 som helhet framträder barnet som aktivt i flera sammanhang, men när det kommer till lärande och inlärningsmiljö så framhävs ofta den vuxnas roll. I anslutning till leken betonas att en god inlärningsmiljö för leken grundar sig "på fostrarnas sakkunnighet om lekens utvecklingsskeden och om lekens kulturella aspekter" (GP05, s. 26).

I GP16 framträder inte det asymmetriska förhållandet mellan vuxen och barn lika tydligt, och det betonas mera en strävan att tillsammans se i samma riktning och skapa en lärande gemenskap (jfr Leinonen, 2014; Varpanen, 2018). Detta gäller inte bara traditionella lärandemiljöer utan även leken. Barn och vuxna ska "uppleva glädjen i att göra och leka tillsammans. Alla i gemenskapen ska uppmuntras att använda sin uppfinningsrikedom, uttrycksförmåga, fantasi och kreativitet. Leken ska få synas och höras" (GP16, s. 29). Samtidigt är det viktigt att" [p] ersonalen ska lägga märke till faktorer som begränsar leken och utveckla arbetssätt och lärmiljöer som främjar lek" (GP16, s. 29). De vuxna tilldelas en reflektiv roll i verksamheten med barnen, för att utöka barns frihet i en positiv bemärkelse, i form av att erbjuda mera möjligheter än vad barnen själva kommer åt att uppfatta (jfr Qvarsell, 2011).

Ett helt nytt begrepp i GP16 är pedagogisk dokumentation som en arbetsmetod för verksamheten. Det övergripande målet är att "[b]arnens kunskaper och färdigheter, intressen och behov" görs synliga genom denna metod, och detta barnens perspektiv "ska utgöra grunden för planeringen av verksamheten" (GP16, s. 37). Detta förstärker ytterligare att barns perspektiv och delaktighet i GP16 ska genomsyra hela verksamhetskulturen, vilket inte var framträdande i GP05. GP16 kräver lyhördhet och sensitivitet av de vuxna, så att både barns perspektiv ("förmåga att lägga märke till barnens initiativ och känslotillstånd") och barns delaktighet ("[b]arnen ska uppmuntras att fråga och fundera samt att dra slutsatser och lösa problem tillsammans") förverkligas (GP16, s. 38).

GP16, jämfört med GP05, har betydligt starkare drag av en sociokulturell lärandekultur. En sociokulturell lärandekultur utgår från tanken om att lärande och utveckling i grunden är en social process och bygger på samspel och kommunikation mellan människor, istället för från en individuell process i människans inre (se t.ex. Säljö, 2000). I GP16 finns inte konkreta pedagogiska anvisningar för hur lärandet ska organiseras, men det finns ett normativt krav att etablera en kultur av stark intersubjektivitet. Tendensen att formulera barnens identitet i termer av "lärande subjekt" förstärks avsevärt med detta (jfr Strandell, 2012, s. 229).

\section{Barns perspektiv och delaktighet i ljuset av samhällskompetens}

Tillkomsten av det senaste styrdokumentet (GP16) motiverades med förändringsprocesser i barnets och dagvårdens verksamhetsmiljö, en förändrad värld samt resultat från forskning och utvecklingsarbete (Helin, Kola-Torvinen \& Tarkka, 2018; GP16). När man jämför de två dokumenten framträder vissa samhällsrelaterade begrepp i 
GP16 som inte diskuterades i GP05.Vi ska i detta sammanhang lyfta fram två sådana begrepp som pekar på en utvidgning av småbarnspedagogikens område.

Tabell 3. Närbesläktade begrepp i anslutning till barns perspektiv och delaktighet i ett samhällsperspektiv.

\begin{tabular}{|l|c|c|}
\hline Närbesläktade begrepp & $\begin{array}{c}\text { Antalet gånger begreppet nämnts } \\
\text { GP05 }\end{array}$ & $\begin{array}{c}\text { Antalet gånger begreppet nämnts } \\
\text { GP16 }\end{array}$ \\
\hline Kompetens & 7 & 63 \\
\hline Demokrati & 0 & 3 \\
\hline
\end{tabular}

Den nya planen, GP16, skapades efter att styrningen av småbarnspedagogik flyttat från social- och hälsovårdsministeriet till kultur- och undervisningsministeriet. Detta innebär rent konkret att småbarnspedagogiken nu, i allt större grad, utvecklas utifrån en gemensam diskurs som den delar med hela den övriga utbildningssektorn i samhället. I den nya planen syns detta särskilt tydligt när det gäller begreppet "mångsidig kompetens" som en del av det livslånga lärandet.

Utvecklingen av mångsidig kompetens börjar i den tidiga barndomen och fortgår hela livet. Målen för mångsidig kompetens löper som en röd tråd genom grunderna för planen för småbarnspedagogik till läroplansgrunderna för förskoleundervisningen och den grundläggande utbildningen (GP16, s. 22).

Kompetensbegreppet nämns överhuvudtaget inte i anslutning till barn i GP05. Det finns därför ingen kontinuitet kring detta från det tidigare planen. Beskrivningen av mångsidig kompetens i GP16 kommer till stora delar direkt från den grundläggande undervisningens läroplan från 2014, men anpassat till en småbarnspedagogisk kontext. Detta innebär att utvecklingen av småbarnspedagogiken bygger till en del på implementering av begrepp som kommer från den grundläggande undervisningen. Kompetensbegreppet i GP16 formuleras utifrån ett perspektiv, där barnet framställs i form av en framtida medborgare, med alldeles särskilda krav på att utveckla vissa färdigheter. Behovet av mångsidig kompetens

uppstår ur de förändringar som sker i den omgivande världen. Att växa som människa, att studera och arbeta samt att fungera som samhällsmedborgare förutsätter både nu och i framtiden kompetenser som överskrider och förenar olika kunskaps- och färdighetsområden (GP16, s. 22).

Den mångsidiga kompetensen i GP16 är indelad i fem olika områden, (1) förmåga att tänka och lära sig, (2) kulturell och kommunikativ kompetens, (3) vardagskompetens, (4) multilitteracitet och digital kompetens samt (5) förmåga att delta och påverka. I detta sammanhang är den sistnämnda kompetensen av särskilt intresse.

Tidigare forskning har uppmärksammat att demokratibegreppet förekommer betydligt oftare i t.ex. Islands, Norges och Sveriges riktgivande styrdokument för småbarnspedagogik än i de finländska (Einarsdottir m.fl., 2015). Trots att 
GP05 utgick från barns rättigheter så nämndes inte begreppet demokrati. Även i GP16 förekommer begreppet sparsamt, endast två gånger och då inom kompetensområdet 'förmåga att delta och påverka'. Här knyts barns perspektiv och delaktighet explicit till demokratibegreppet på två olika sätt. Å ena sidan som en rättighetsprincip:

Till barnens rättigheter hör att bli hörda och att vara delaktiga i frågor som påverkar deras liv. Inom småbarnspedagogiken respekterar man dessa centrala demokratiska principer (GP16, s. 24).

Å andra sidan som någonting oumbärligt för framtidens samhälle:

Förmåga att delta och påverka på ett aktivt och ansvarsfullt sätt lägger grunden för en demokratisk och hållbar framtid. Det förutsätter att individen har förmåga och vilja att delta i den gemensamma verksamheten och litar på sina möjligheter att påverka (GP16, s. 24).

Här ser man att småbarnspedagogiken lägger grunden för en demokratisk attityd där de vuxna ska ha en förmåga att kunna inta barns perspektiv genom "[a]tt bemöta barnen med respekt, ta hänsyn till deras tankar och bemöta deras initiativ" vilket "stärker barnens förmåga att delta och påverka" (GP16, s. 25). Men vid sidan av att synliggöra barns tankar och intressen behöver vi skapa en kultur av samverkan, där

[b]arnen ska planera, genomföra och utvärdera verksamheten tillsammans med personalen. Barnen lär sig då samtidigt att kommunicera och att förstå betydelsen av gemensamma regler, överenskommelser och tillit (GP16, s. 25).

Barnen lär sig vad demokrati innebär genom att bli sedda som unika individer och beredas möjlighet att samverka i fråga om gemensamma angelägenheter. Mot bakgrund av vår tidigare diskussion om delaktighet i ljuset av negativ och positiv frihet så förefaller GP16 beakta båda sidorna, de är som två sidor av samma mynt. Barns möjlighet att påverka sin omgivning sker alltid i sociala sammanhang som kan vara mer eller mindre öppna. Därför har de vuxna alltid ansvar att normkritiskt granska olika hinder som kan finnas i vägen.

Småbarnspedagogiken främjar det finländska samhällets demokratiska värderingar [...] Barnen ska ges möjligheter att utveckla sina färdigheter och göra sina val oberoende av förväntningar baserade till exempel på kön, ursprung, kulturell bakgrund eller andra orsaker som gäller barnet som person (GP16, s. 19).

Från 1990-talet och framåt har småbarnspedagogiken i Norden till en stor del fått sin legitimitet genom en retorik som betonar barnets individualitet, en beskrivning av det kompetenta barnet som får möjlighet att välja och lära sig utifrån sina individuella intressen (se Kampmann, 2004). Genom införandet av demokratibegreppet i 
GP16, visserligen sparsamt, har man kommit åt att betona delaktighet i ett bredare spektrum - i ljuset av samverkan i gemensamma angelägenheter (se Moss, 2007).

Det är intressant att GP05 inte behandlade barns perspektiv och delaktighet nämnvärt ur ett samhälleligt perspektiv. I GP16 motiveras begreppen med en tydlig riktning utifrån ett demokratiskt samhällsprojekt, som kräver en lärandekultur där "kunskaper och färdigheter som barnen tillägnar sig i den småbarnspedagogiska verksamheten stärker deras delaktighet och aktiva deltagande i samhället" (GP16, s. 14). Med GP16 etableras en ny samhällstillvänd och pedagogiskt färgad diskurs, med barnet som en framtida medborgare (se James, 2012), inom den finländska småbarnspedagogiken.

\section{Sammanfattning}

Föreställningar om barn är alltid ideologiskt färgade. Från upplysningstiden och framåt, inte minst genom Rousseau och Fröbel, har man kommit att beskriva barn som individer, med egna unika erfarenheter som bör värdesättas och beaktas. Dessa tankar fick förnyad aktualitet mot slutet av 1900-talet i anslutning till FN:s konvention om barnets rättigheter där barnet som subjekt och aktör kom i fokus. De nordiska länderna har i större utsträckning än kanske någon annan region i världen omsatt barnkonventionens principer i praktiken. Det syns i den nordiska politiken inom barnomsorgen och alldeles särskilt i betonandet av barns perspektiv, röst och delaktighet (Eydal, 2012, s. 40).

Vi har i denna artikel fokuserat på hur barns perspektiv och delaktighet implementerats i den finländska småbarnspedagogiken. I vår analys kom vi fram till att när man jämför styrdokumenten från 2005 och 2016 så framträder en tydlig skillnad. I GP05 artikulerades en syn på barnet som aktivt och nyfiket på sin omvärld men $i$ högre grad beroende av vuxna. I olika sammanhang utgår man från barnets bästa och barnet som subjekt, men själva verksamhetskulturen initieras och styrs av vuxna, utan explicita krav på att synliggöra barns intressen eller barns perspektiv. Betoningen i GP05 ligger på ett barnperspektiv, snarare än på barns perspektiv. I GP16 beskrivs barnet och vuxna däremot sällan i ett asymmetriskt förhållande, utan istället betonas barns perspektiv som ett viktigt fundament för verksamhetskulturen. Barns perspektiv tematiseras i flera olika sammanhang, dels i anslutning till barns aktörskap och delaktighet, dels till en sociokulturell lärandekultur och kompetensdiskurs. Barnet har i det senaste styrdokumentet (GP16) alltså fått en betydligt starkare roll som såväl aktör, lärandesubjekt som samhällsmedborgare. Samma betoning finner man i forskning kring delaktighet i Finland från de senaste åren (se Leinonen, 2014; Kangas, 2016; Turja \& Vuorisalo, 2018).

Begreppet delaktighet har breddats avsevärt inom småbarnspedagogiken i Finland genom GP16. Barns delaktighet har utvecklats i en riktning där individ- och gemenskapsperspektivet (frihet i negativ och positiv bemärkelse) kompletterar varandra. Barnets rättigheter till ett pedagogiskt sammanhang utgör ett viktigt komplement till barnets individuella rättigheter (att se barnet, barns initiativ och inflytande). Detta är 
i linje med Emilsons och Johanssons (2018) observation att förståelsen av demokrati inom den nordiska småbarnspedagogiken håller på att förskjutas från individuella rättigheter till mera kollektivt orienterade perspektiv. Som vi har kunnat se så har demokratibegreppet långsamt etablerat sig inom den finländska småbarnspedagogiken (jfr Einarsdottir m.fl., 2015), och kommer in i GP16 i anslutning till en diskussion kring barns perspektiv och delaktighet. Rörelsen går också här i riktning från ett individperspektiv till ett mera samhällsorienterat perspektiv.

Det har påpekats att universalismen inom småbarnspedagogiken under 2000-talet i Finland har kommit att ersättas av en individualiserad syn på utveckling, där barnet som subjekt och en unik personlighet kommit i förgrunden, och till vars rättigheter hör en möjlighet att välja och att få bejaka sina individuella intressen (Strandell, 2012, s. 235; Kjørholt \& Qvortrup, 2012). I kölvattnet av en nyliberal och marknadsorienterad politisk diskurs kan man därför fråga sig om småbarnspedagogiken löper risk att skapa en institutionaliserad barndom där barnen uppmuntras följa sina egna preferenser och fostras till konsumentskap med frihet att välja, snarare än att uppmuntras till att samverka med andra (jfr Jansen, Johansson \& Ødegaard, 2011, s. 63). Utgående från vår läsning av styrdokumenten ser vi rätt lite som stöder en dylik utveckling. Visserligen har det kommit in begrepp i GP16, som kompetens och livslångt lärande, som kan betraktas i ljuset av en nyliberal politisk tradition. Samtidigt anger den starka betoningen av barns perspektiv och barns delaktighet utifrån en sociokulturell referensram tydliga riktlinjer för hur begreppen ska tolkas. Man fäster mycket uppmärksamhet vid den positiva friheten, dvs. frihet i ljuset av samverkan och känsla av sammanhang.

Sammanfattningsvis kan vi säga att den nya ideologiska orienteringen inom den finländska småbarnspedagogiken balanserar mellan tradition och nyskapande. Utmaningen är att hitta en jämvikt mellan det värdefulla i den egna traditionens praktiker, och den nya strävan att tala och utveckla småbarnspedagogiken i ett lärandeperspektiv, något som t.ex. i Sverige har medfört att undervisningsbegreppet vunnit terräng inom den tidiga barndomen (se Eidevald \& Engdahl, 2018). Det har funnits ett hårt politiskt tryck för Finland att utveckla pedagogiken för barn under skolåldern. När de betydelsefulla pedagogiska reformerna nu har genomförts så ligger Finland ännu närmare den nordiska småbarnspedagogiska gemenskapen jämfört med tidigare.

\section{Författarbiografi}

Jan-Erik Mansikka arbetar som universitetslektor i pedagogik vid Helsingfors universitet, Finland. Hans forskning spänner över ett brett område som på olika sätt relaterar till mångfaldsfrågor inom pedagogiken. Jan-Erik är också verksam som timlärare vid Konstuniversitetet, avdelningen för musikfostran.

Marina Lundkvist arbetar som universitetslektor i pedagogik, inriktning mot småbarnspedagogik, vid Helsingfors universitet, Finland. Hennes forskning omfattar 
frågeställningar kring demokrati, värdefostran, barnets rättigheter och delaktighet inom småbarnspedagogiken.

\section{Referenser}

Alasuutari, M. (2009). Kasvatusinstituutiot lapsuuden rakentajana. Teoksessa L. Alanen \& K. Karila (toim.) Lapsuus, lapsuuden instituutiot ja lasten toiminta (s. 54-69). Tampere: Vastapaino.

Alila, K., Eskelinen, M., Estola, E., Kahiluoto, T., Kinos, J., Pekuri H.-M., Polvinen, M., Laaksonen, R., \& Lamberg, K. (2014). Varhaiskasvatuksen historia, nykytila ja kehittämisen suuntalinjat. Tausta-aineisto varhaiskasvatusta koskevaa lainsäädäntöä valmistelevan työryhmän tueksi [Småbarnspedagogikens historia, nuläge och utvecklingens riktlinjer. Bakgrundsmaterial som har tagits fram för att stödja arbetsgruppen som förbereder lagstiftningen inom småbarnspedagogiken]. Opetus- ja kulttuuriministeriön työryhmämuistioita ja selvityksiä 2014:12.

Arendt, H. (2004). Mellan det förflutna och framtiden. Göteborg: Daidalos.

Arnér, E., \& Tellgren, B. (2006). Barns syn på vuxna - att komma nära barns perspektiv. Studentlitteratur.

Berlin, I. (1969). Four essays on liberty. Oxford: Oxford University Press.

Brotherus, A., Hytönen, J., \& Krokfors, L. (2002). Esi-ja alkuopetuksen didaktiikka. Juva: WSOY.

Brotherus, A. \& Kangas, J. (2018). Leikkiympäristön haasteet ja rajoitukset lasten osallisuudelle. Teoksessa J. Kangas, J. Vlasov, E. Fonsén \& J. Heikka, (toim.) Osallisuuden pedagogiikkaa varhaiskasvatuksessa 2 Suunnittelu, toteuttaminen ja kehittäminen (s. 20-34). Tampere: Suomen Varhaiskasvatus ry.

Bryman, A. (2011). Samhällsvetenskapliga metoder. Stockholm: Liber.

Council of Europe (2011). Child and youth participation in Finland. A Council of Europe policy review. Strasbourg: Directorate General of Social Cohesion.

Dolk, K. (2013). Bångstyriga barn. makt, normer och delaktighet i förskolan. Stockholm: Ordfront förlag.

Eidevald, C., \& Engdahl, I. (2018). Utbildning och undervisning i förskolan. Stockholm: Liber.

Einarsdottir, J., Purola, A.-M., Johansson, E. M., Broström, S., \& Emilson, A. (2015). Democrazy, caring and competence: values perspectives in ECEC curricula in the Nordic countries. International fournal of Early Years Education, 23(1), 97-114.

Emilson, A., \& Johansson, E. (2018). Values in Nordic Early Childhood Education - Democracy and the Child's Perspective. In M. Fleer and B. van Oers (eds.) International Handbook on Early Childhood Education and Development. Dordrecht: Springer.

Eriksen, E. (2018). Democratic Participation in Early Childhood Education and Care - Serving the Best Interest of the Child. Fournal of Nordic Early Childhood Education Research 17(10), 1-15.

Eydal, G. B. (2012). Childcare Policies at a Crossroad. The case of Iceland. In T. Kjörholt \& J. Qvortrup (eds.) The Modern Child and the Flexible Labour Market (pp. 38-55). Hampshire: Palgrave MacMillan.

Garvis, S., Phillipson S., \& Harju-Luukkainen, H. (2018). (eds.) An introduction to Early Childhood Education and Care in the 21st Century: An international perspective. United Kingdom, Routledge.

GP 05. Stakes (2005). Grunderna för planen för småbarnsfostran. Handböcker 61.

GP 16. Utbildningsstyrelsen (2016). Grunderna för planen för småbarnspedagogik. Föreskrifter och anvisningar 2016: 17 .

Halldén, G. (2003). Barnperspektiv som ideologiskt eller metodologiskt. Pedagogisk forskning $i$ Sverige 8(1-2), 12-23.

Helin, E., Kola-Torvinen, P. \& Tarkka, K. (2018). Osallisuus ja osallistuminen varhaiskasvatussuunnitelman perusteissa. Teoksessa J. Kangas, J. Vlasov, E. Fonsén, \& J. Heikka, (toim.) Osallisuuden pedagogiikkaa varhaiskasvatuksessa 2 - Suunnittelu, toteuttaminen ja kehittäminen (s. 11-19). Tampere: Suomen Varhaiskasvatus ry.

Hytönen, J. (1992). Lapsikeskeinen kasvatus. Porvoo: WSOY.

Hännikäinen, M., \& Rasku-Puttonen, H. (2010). Promoting children's participation: the role of teachers in preschool and primary school learning sessions. Early Years. An International fournal of Research and Development, 30(2), 147-160.

James, A. (2012). 'Child-Centredness' and 'the Child'. The Cultural Politics of nursery Schooling in England. I Kjørholt, T. \& Qvortrup J. The Modern Child and the Flexible Labour Market. Hampshire: Palgrave MacMillan, 111-127. 


\section{Fan Erik Mansikka og Marina Lundkvist}

Jansen, K., Johansson, E., \& Ødegaard, E. (2011). På jakt etter demokratibegreper i barnehagen. Nordisk Barnehageforskning 4(2), 61-64.

Johansson, E. (2003). Att närma sig barns perspektiv. Forskares och pedagogers möten med barns perspektiv. Pedagogisk forskning $i$ Sverige 8:1-2, 42-57.

Kampmann, J. (2004). Societalization of Childhood: New Opportunities? New Demands? In Brembeck, H., Johansson, B. and Kampmann, J. (eds.) Beyond the competent child. Exploring Contemporary Childhoods in the Nordic Welfare States. Roskilde: Roskilde University Press.

Kangas, J. (2016). Enhancing children's participation in early childhood education through the participatory pedagogy. (Diss.) Department of Teacher Education. University of Helsinki.

Karila, K. (2006). Kasvatuskumppanuus vuorovaikutussuhteena. Teoksessa K. Karila, M, Alasuutari, M. Hännikäinen, A. R. Nummenmaa \& H. Rasku-Puttonen. (toim.) Kasvatusvuorovaikutus. Tampere: Vastapaino. 91-108.

Karila, K. (2009). Lapsuudentutkimus ja päiväkotien toiminta. Teoksessa Alanen, L. \& Karila, K. (toim.) Lapsuus, lapsuuden instituutiot ja lasten toiminta (s. 249-262). Tampere:Vastapaino.

Karlsson, L. (2012). Lapsinäkökulmaisen tutkimuksen ja toiminnan poluilla. Teoksessa L. Karlsson \& R. Karimäki (toim.) Sukelluksia lapsinäkökulmaiseen tutkimukseen ja toimintaan (s. 17-63). Kasvatusalan tutkimuksia 57. Jyväskylä: Suomen kasvatustieteellinen seura.

Kinos, J. (2002). Kohti lapsilähtöisen varhaiskasvatuksen teoriaa. Kasvatus 33(2), 119-132.

Kjørholt, T., \& Qvortrup J. (2012). The Modern Child and the Flexible Labour Market. Hampshire: Palgrave MacMillan.

Lag om barnombudsmannen 1221/2004.

Lag om ändring av lagen om barndagvård 580/2015.

Lag om småbarnspedagogik 540/2018.

Leinonen, J. (2014). Pedagogisia näkökulmia lasten osallisuuden tukemiseen varhaiskasvatuksessa. Teoksessa J. Heikka, E. Fonsén, J. Elo \& J. Leinonen (toim.) Osallisuuden pedagogiikkaa varhaiskasvatuksessa (s. 16-40). Tampere: Suomen Varhaiskasvatus ry.

Lundkvist, M. (2015). Delaktighet - en central aspekt av demokrati inom småbarnspedagogik. I E. AhlskogBjörkman \& A.-C. Furu. (Red.), Forskningsperspektiv på barnträdgårdslärares professionalism. Rapport nr 37 från Fakulteten för pedagogik och välfärdsstudier, Vasa.

Lundkvist, M. (2016). Vad innebär det att bli demokratisk? Dimensioner av demokrati i mötet mellan barn och pedagoger. (Diss.). Vasa: Åbo Akademi.

Meretniemi, M. (2015). Hyvä koti ja henkinen äitiys lastentarhatyön esikuvina. Helsingin yliopisto. Opettajankoulutuslaitos. Tutkimuksia 369

Moss, P. (2007). Bringing politics into nursery: early childhood education as a democratic practice. European Early Childhood Education Research fournal 15:1, 5-20.

Niikko, A. (2009). Varhaiskasvatuksen lapsikeskeisyyden perusta on monitieteisessä ajattelussa. Kasvatus 40(1) 69-82.

Pramling Samuelsson, I., Sommer, D., \& Hundeide, K. (2011). Barnperspektiv och barnens perspektiv i teori och praktik. Stockholm: Liber.

Puroila, A.-M., \& Kinnunen, S. (2017). Utredning om verkningarna av ändringarna $i$ lagstiftningen om småbarnspedagogik. Publikationsserie för statsrådets utrednings- och forskningsverksamhet 78/2017.

Qvarsell, B. (2011). Demokrati som möjlighet i små barns liv och verksamhet. Nordisk Barnhageforskning 4(2), $65-74$.

Reinikka, R., Niemi, H., \& Tulivuori, J. (2018). Stepping Up Finland's Global Role in Education. Niras. Ministry for Foreign Affairs in Finland.

Sahlberg, P. (2015). Finnish lessons 2.0: what can the world learn from educational change in Finland? New York: Teachers College Press.

Satka, M. \& Eydal, G. B. (2004). The History of Nordic Welfare Policies for Children. In H. Brembeck, B. Johansson and J. Kampmann (eds.) Beyond the Competent Child. Exploring Contemporary Childhoods in the Nordic Welfare States (pp. 33-61). Roskilde: Roskilde University Press.

Simola, H. (2015). The Finnish Education Mystery: Historical and Sociological Essays on Schooling in Finland. London and New York: Routledge.

Strandell, H. (2012). Policies of Early Childhood Education and Care. I Kjörholt, T., \& Qvortrup, J. The Modern Child and the Flexible Labour Market. Hampshire: Palgrave MacMillan, 222-240. 
Säljö, R. (2000). Lärande i praktiken: ett sociokulturellt perspektiv. Stockholm: Prisma.

Tjora, A. (2012). Från nyfikenhet till systematisk kunskap. Kvalitativ forskning i praktiken. Lund: Studentlitteratur. Turja, L. (2017). Lasten osallisuus varhaiskasvatuksessa. I Hujala, E., \& Turja, L. (eds.) Varhaiskasvatuksen käsikirja. Juva: PS-Kustannus.

Turja, L. \& Vuorisalo, M. (2017). Lasten oikeudet, toimijuus ja osallisuus oppimisessa. Teoksessa M. Koivula, A. Siippainen \& P. Eerola-Pennanen (toim.) Valloittava varhaiskasvatus. Oppimista, osallisuutta ja hyvinvointia (s. 36-55). Tampere: Vastapaino.

Varpanen, J. (2018). Vapaus, demokratia ja jaettu todellisuus osallisuuden ytimessä. Teoksessa J. Kangas, J. Vlasov, E. Fonsén \& J. Heikka, (toim.) Osallisuuden pedagogiikkaa varhaiskasvatuksessa 2 - Suunnittelu, toteuttaminen ja kehittäminen (s. 120-134). Tampere: Suomen Varhaiskasvatus ry.

Venninen, T., \& Leinonen, J. (2013). Developing children's participation through reflective practice. Asia-Pacific fournal of early childhood education 7(1), 1-19.

Venninen, T., Leinonen, J., Lipponen, L., \& Ojala, M. (2014). Supporting children's participation in Finnish child care centres. Early Childhood Education fournal 42, 211-218.

Widén, P. (2009). Kvalitativ textanalys. I A. Fejes \& R. Thornberg (Red.). Handbok i kvalitativ analys. Stockholm: Liber. 